\title{
Processed cheese sauces with different preservative systems
}

\author{
Suhila A Saad ${ }^{1}$, Laila D EL-mahdi ${ }^{1}$, RA Awad ${ }^{2}$ and ZMR Hassan ${ }^{2}$ \\ ${ }^{1}$ Food Technology Research Institute (FTRI), Agricultural Research Center, Giza, Egypt \\ ${ }^{2}$ Food Science Department, Faculty of Agriculture, Ain Shams University, Cairo, Egypt
}

\begin{abstract}
Five Formulations of processed cheese sauces with different preservatives systems were achieved in this study. The incorporated ingredients used to introduce shelf life stable processed cheese sauces with formulations consists of: Ras cheese, UF- retentate curd, butter fat, corn starch \& guar gum, skim milk powder, emulsifying salt, preservative system: Nisin, Nisin + Natamycin, Nisin + Potassium sorbate or Nisin + Natamycin + Potassium sorbate. All formulated processed cheese sauces blends were adjusted to contain $25 \% \mathrm{TS}, 40 \% \mathrm{~F} / \mathrm{DM}$, in the processed cheese sauce as a finished product. Addition of the preservatives in cheese sauce formula has a significant effect on the keeping properties. Nisin + Potassium sorbate mixture has no undesirable effect on the chemical, physical and sensory properties even after 3 months of storage. Resultant processed cheese sauces were evaluated when fresh and periodically during storage at $\left(25 \pm 2^{\circ} \mathrm{C}\right)$ for chemical composition, $\mathrm{pH}$, oil separation index and viscosity. All treatments were also examined for microbiological and sensory quality attributes when fresh and during storage up to 3 months. Three replicates were carried out for each treatment and the data obtained were statistically analyzed at $\mathrm{p} \leq 0.05$.
\end{abstract}

\section{Introduction}

Cheese sauce contains mixture of ingredients such as natural cheese, dairy components, fat, starch or hydrocolloids with high moisture content. These ingredients may contain microbial spoilage especially natural cheese. Bacterial cells, yeast \& mould and spores often present in raw cheese used for processing, and can survive in spite of heating which achieved during the melting process. The outgrowth of spores which may result in subsequent spoilage that causes production of gas \& off flavour and liquefaction of the cheese. Studies were conducted to develop safety standard for the processing of shelf stable cheese products. The uses of preservatives were effective and allow cheese sauce to be stored outside chill cabinets without the risk of spoilage. Preservatives are natural or synthetic chemicals that are added to foods products to prevent decomposition by microbial growth or by undesirable chemical changes. Preservative food additives can be used individually or in conjunction with other methods of food preservation. Preservatives may be anti-microbial or antifungal, which inhibit the growth of bacteria and fungi, or antioxidants such as oxygen absorbers, which inhibit the oxidation of food constituents. In addition, the cheese sauce includes preservative or antimicrobials. The functions of food antimicrobials are to inhibit or inactivate spoilage microorganisms and pathogenic microorganisms. The latter function has increased with importance in the past $10-15$ years as food processors search for more and better tools to improve food safety. A number of compounds are approved by international regulatory agencies for use as direct food antimicrobials such as nisin, natamycin and sorbate salts. The question arises as to why, with so many compounds already approved for use in foods!. Would the food processing industry need a greater number of food antimicrobials?. The primary incentive for searching about effective antimicrobials among naturally occurring compounds is to expand the spectrum of antimicrobials activity over that of the regulatory - approved substances. Cheese sauce may have less keeping quality due to its high moisture content and low salt/ moisture ratio. Several types of preservative materials in single form have been introduced to extend the shelf stability of cheese sauce. The use of preservatives mixtures of two or more preservative materials may have a synergistic effect and can extend the shelf life period of such product with that high moisture content.

Since cheese sauce is a food system that has high moisture content with high water activity and can be considered as a low shelf life stable product compared to similar products as processed cheese. Therefore, this study was designed to investigate the effect of different preservative materials either single or in combinations to obtain the best preservative system that can be used in cheese sauce production. A combination of nisin, natamycin or potassium sorbate have been tried and compared to nisin as individual standard preservative and also compared to control with no preservative material.

\section{Materials and methods}

\section{Materials}

Ras cheese was purchased from the local market, Cairo, Egypt. Skim milk powder used in this study was obtained from Dina farmer, Cairo, Egypt. Corn starch was obtained from the starch and glucose company, Cairo, Egypt. Guar gums were obtained from Gumix International, Inc. Fort Lee, NJ. Butter oil brand name NZ imported from New Zealand Dairy Board, Wellington, New Zealand was obtained from the local market, Cairo, Egypt. Commercial emulsifying salt $\mathrm{S}_{9}$ special were obtained from JOHA BK Ladenburg corp., GmbH, Ladenburg, Germany. Nisin and natamycin used as preservatives in

Correspondence to: Suhila A Saad, Food Technology Research Institute (FTRI), Agricultural Research Center, Giza, Egypt, E-mail: suhilasaad@yahoo.com

Key words: Processed cheese sauces, uf-retentate curd ( $u f-r c$ ), skim milk powder, corn starch, guar gum, nisin, natamycin, potassium sorbate and preservative systems

Received: December 19, 2014; Accepted: January 26, 2015; Published: January 30, 2015 
this study were produced by Zhejiang silver elephant Bio - Engineering Co., China, and were obtained from Amson international trading, Giza - Egypt. Potassium sorbate was obtained from EL-Nasr for chemicals industries, Cairo, Egypt and used as a preservative.

\section{Methods of manufacture}

Preparation of UF-retentate curd (UF-RC): Soft cheese curd was manufactured using UF-retentate according to the method described by Suhila [1] as follows:

UF-retentate was warmed up to $40^{\circ} \mathrm{C}$. Sodium chloride $(\mathrm{NaCl})$ was added to the warm retentate at ratio $3 \%(\mathrm{w} / \mathrm{w})$ and well mixed. Calcium chloride $0.01 \%$ of $40 \%$ solution was then added to UF-retentate to improve the coagulation process. Calf rennet powder was added to coagulate the retentate within $20-25 \mathrm{~min}$. After coagulation the curd was cooled in the refrigerator and prepared for making the processed cheese sauce.

Processed cheese sauce manufacture: Ras cheese blocks were cut into small portions suitable to be fed through the inlet of a shredding machine (Braun mincer, Germany). Shredded cheese was milled in milling machine, (National, Japan). Suitable amount of Ras cheese, skim milk powder, butter, $\mathrm{NaCl}$, preservative system, stabilizer mixture and emulsifying salt were added consecutively in a laboratory styleprocessing Kettle locally made in Egypt. Specifications of the cooking machine were previously mentioned by Awad [2]. The ingredients were mixed for about $1 \mathrm{~min}$ before processing. Control treatment was adjusted to have the same composition without adding preservative system. The mixture was cooked for $10 \mathrm{~min}$ at $85-90^{\circ} \mathrm{C}$ using indirect heated steam at pressure of $1.5-2.0 \mathrm{Kg} / \mathrm{cm}^{2}$. The melted processed cheese sauce was purred into glass jars $(150 \mathrm{~g})$ and capped directly after filling. The resultant cheese sauce was cooled at room temperature and then analyzed when fresh and monthly up to 3 months during storage at room temperature $\left(25 \pm 2^{\circ} \mathrm{C}\right)$.

\section{Methods of analyses}

Chemical analysis: Cheese sauce samples were tested for Moisture, Fat, salt, ash contents as mentioned by AOAC [3]. Total nitrogen (TN) and soluble nitrogen (SN) contents were measured using the semi micro-Kjeldal method according to the method described by Ling [4]. Total volatile fatty acids (TVFA) value was determined according to the method described by KosiKowski [5] and values were expressed as $\mathrm{ml}$ of $0.1 \mathrm{~N} \mathrm{NaOH} / 100 \mathrm{~g}$ cheese sauce.

Physicochemical properties: Values of $\mathrm{pH}$ were measured using the electric HANNA instrument $\mathrm{pH} 213$ microprocessor $\mathrm{pH}$ meters by inserting the $\mathrm{pH}$ combined glass electrode (Electric Instruments limited) directly in the sample. Values of $\mathrm{pH}$ were reported to nearest 0.01 units.

\section{Physical properties}

Oil separation index (OSI): Oil separation index of processed cheese sauce was determined as described by Thomas [6]. It could be summarized as follows:

A cork borer was used to obtain cylindrical samples of processed cheese sauce approximately $17.0 \mathrm{~mm}$ X $17.0 \mathrm{~mm}$. The sample was pressed gently between Whatman filter paper No. 41 and incubated at $45^{\circ} \mathrm{C}$ for two hours. The diameter of the spread oil \& water was measured in $\mathrm{mm}$ and used as an oil and water separation index as follows:

Oil and water separation index $=(\mathrm{A}-\mathrm{B}) / \mathrm{B}$ X 100

\section{A: Diameter of spread after heating.}

\section{B: Diameter of spread before heating.}

Viscosity: Viscosity of processed cheese sauce samples was measured according to Viturawong et al. [7] using a coaxial rotational viscometer, Brookfield Engineering labs DV- III ultra rheometer, at shear rates ranging from 12.411 to $74.467 \mathrm{sec}^{-1}$. The measuring device spindle (HA-07) was used with a sample volume of $110 \mathrm{~g}$ per run. The apparent viscosity was recorded at all shear rates.

\section{Micrbiological analysis}

Viable Total bacterial count (VTBC): Total viable bacterial count was enumerated using nutrient agar medium according to the method described in Oxoid [8]. The plates were incubated aerobically at $32^{\circ} \mathrm{C}$ for $48 \mathrm{~h}$.

Aerobic spore formers bacterial count: Aerobic spore formers bacterial count was enumerated using nutrient agar medium according to the method described in Oxoid [9]. The samples of processed cheese sauces were heated to $80^{\circ} \mathrm{C}$ for $10 \mathrm{~min}$ in a water bath and cold immediately to $10^{\circ} \mathrm{C}$ before preparing the dilutions. The plates were incubated aerobically at $32^{\circ} \mathrm{C}$ for $48 \mathrm{~h}$.

Anaerobic spore formers bacterial count: Anaerobic spore formers bacterial count was enumerated using nutrient agar medium according to the method described in Oxoid [9]. Samples were heated to $80^{\circ} \mathrm{C}$ for $10 \mathrm{~min}$ and cooled immediately to $10^{\circ} \mathrm{C}$ before preparing the dilutions. The plates were incubated under anaerobic conditions at $32^{\circ} \mathrm{C}$ for $48 \mathrm{~h}$.

Yeast and mould count: Yeast and mould count were enumerated using yeast and mould agar medium according to the method described in Oxoid [9]. The plates were incubated at $20^{\circ} \mathrm{C}$ for $3-5$ days.

Sensory evaluation: Sensory evaluation was carried out according to the Scheme of Meyer [10]. The evaluation was done by regular scoring panel of members in the Food Science Department, Faculty of Agriculture, Ain Shams University and Dairy department, Food Technology Research Institute, Agriculture Research Center.

Statistical analysis: Statistical analysis was performed according to SAS Institute [11] using General Linear Model (GLM). Duncan's multiple rang was used to separate among means of three replicates of samples.

\section{Results and discussions}

\section{Total solids and fat/dry matter}

Total solid and fat/DM contents of processed cheese sauces as affected by adding preservative systems are shown in Table 1 . The data cleared that there were very slight and non significant differences in total solid contents and F/DM ratio of all treatments. The average of total solids was 25.36 while the average of F/DM ratio was 40.32 . These slight differences could be related to the slight differences during weighting and formulating the blends.

\section{Total nitrogen (TN) and Ash content}

Total nitrogen (TN) contents of processed cheese sauces as affected by adding different mixtures of preservatives are stated in Table 2 . Total nitrogen (TN) contents exhibited values of $1.27,1.25,1.26,1.24$ and 1.24 meanwhile, ash content exhibited values of $2.92,2.86,2.89$, 2.84 and 2.82 for control cheese sauce with no added preservatives and cheese sauces with nisin, nisin + natamycin, nisin + potassium sorbate 
Table 1. Chemical composition (\%) of processed cheese sauces with different preservatives systems

\begin{tabular}{|c|c|c|c|c|c|}
\hline Treatments* & Total solids & F/DM & Total nitrogen & Ash & Salt/moisture \\
\hline $\mathbf{C}$ & 25.52 & 40.67 & 1.27 & 2.92 & 1.17 \\
\hline $\mathbf{T}_{\mathbf{1}}$ & 25.51 & 40.28 & 1.25 & 2.86 & 1.15 \\
\hline $\mathbf{T}_{\mathbf{2}}$ & 25.49 & 40.37 & 1.26 & 2.89 & 1.16 \\
\hline $\mathbf{T}_{\mathbf{3}}$ & 25.28 & 40.21 & 1.24 & 2.84 & 1.14 \\
\hline $\mathbf{T}_{\mathbf{4}}$ & 25.01 & 40.11 & 1.24 & 2.82 & 1.13 \\
\hline
\end{tabular}

C-Control with no added preservative

$\mathrm{T}_{1}$-Nisin

$\mathrm{T}_{2}$-Nisin + Natamycin

$\mathrm{T}_{3}$-Nisin + Potassium sorbate

$\mathrm{T}_{4}$-Nisin + Natamycin + Potassium sorbate

Table 2. The $\mathrm{pH}$ values of processed cheese sauces with different preservatives systems when fresh and during storage at $\left(25^{\circ} \mathrm{C}\right)$.

\begin{tabular}{|c|c|c|c|c|}
\hline \multirow{2}{*}{ Treatments* $^{*}$} & \multirow{2}{*}{ Fresh } & \multicolumn{3}{|c|}{ Storage period/month } \\
\cline { 3 - 5 } & & $\mathbf{1}$ & $\mathbf{2}$ & $\mathbf{3}$ \\
\hline $\mathbf{C}$ & $5.82^{\mathrm{Aa}}$ & $5.70^{\mathrm{Bb}}$ & $5.65^{\mathrm{Bb}}$ & $5.55^{\mathrm{Bc}}$ \\
\hline $\mathbf{T}_{1}$ & $5.84^{\mathrm{Aa}}$ & $5.80^{\mathrm{Aa}}$ & $5.75^{\mathrm{Aa}}$ & $5.60^{\mathrm{ABb}}$ \\
\hline $\mathbf{T}_{2}$ & $5.83^{\mathrm{Aa}}$ & $5.78^{\mathrm{ABab}}$ & $5.70^{\mathrm{ABbc}}$ & $5.62^{\mathrm{ABc}}$ \\
\hline $\mathbf{T}_{3}$ & $5.85^{\mathrm{Aa}}$ & $5.81^{\mathrm{Aab}}$ & $5.73^{\mathrm{ABbc}}$ & $5.65^{\mathrm{Ac}}$ \\
\hline $\mathbf{T}_{4}$ & $5.85^{\mathrm{Aa}}$ & $5.80^{\mathrm{Aab}}$ & $5.72^{\mathrm{ABbc}}$ & $5.63^{\mathrm{ABc}}$ \\
\hline
\end{tabular}

*see Table (1)

A, B, C: Means with the same letter among treatments in the same storage period are not significantly different.

$\mathrm{a}, \mathrm{b}$, c: Means with the same letter in the treatment during storage periods are not significantly different.

Table 3. Soluble nitrogen content (\%) of processed cheese sauces with different preservatives systems when fresh and during storage at $\left(25^{\circ} \mathrm{C}\right)$.

\begin{tabular}{|c|c|c|c|c|}
\hline \multirow{2}{*}{ Treatments* $^{*}$} & \multirow{2}{*}{ Fresh } & \multicolumn{3}{|c|}{ Storage period/month } \\
\cline { 3 - 5 } & & $\mathbf{1}$ & $\mathbf{2}$ & $\mathbf{3}$ \\
\hline $\mathbf{C}$ & $0.779^{\mathrm{Ac}}$ & $0.815^{\mathrm{Abc}}$ & $0.989^{\mathrm{Aab}}$ & $1.137^{\mathrm{Aa}}$ \\
\hline $\mathbf{T}_{\mathbf{1}}$ & $0.766^{\mathrm{Ab}}$ & $0.798^{\mathrm{Ab}}$ & $0.907^{\mathrm{Ab}}$ & $1.104^{\mathrm{Aa}}$ \\
\hline $\mathbf{T}_{\mathbf{2}}$ & $0.777^{\mathrm{Ab}}$ & $0.811^{\mathrm{Ab}}$ & $0.849^{\mathrm{Ab}}$ & $1.054^{\mathrm{Aa}}$ \\
\hline $\mathbf{T}_{3}$ & $0.765^{\mathrm{Ab}}$ & $0.804^{\mathrm{Ab}}$ & $0.892^{\mathrm{Aab}}$ & $1.031^{\mathrm{Aa}}$ \\
\hline $\mathbf{T}_{\mathbf{4}}$ & $0.756^{\mathrm{Ab}}$ & $0.784^{\mathrm{Ab}}$ & $0.876^{\mathrm{Aab}}$ & $1.018^{\mathrm{Aa}}$ \\
\hline
\end{tabular}

*see Table (1)

A, B, C: Means with the same letter among treatments in the same storage period are not significantly different.

a, b, c: Means with the same letter in the treatment during storage periods are not significantly different.

and nisin + natamycin + potassium sorbate consecutively. The results indicated that there were no great differences in TN and either ash contents among all treatments.

\section{Salt/moisture}

Salt/moisture content of processed cheese sauces as affected by adding different mixtures of preservatives are stated in Table 2. The data revealed that salt / moisture content were 1.17, 1.15, 1.16, 1.14 and 1.13 for control cheese sauce with no added preservatives and cheese sauces with nisin, nisin + natamycin, nisin + potassium sorbate and nisin + natamycin + potassium sorbate respectively. These slight differences in salt / moisture among all treatments due to the differences of ingredients weight used to formulate the base blends, mainly due to Ras cheese the main domain of salt.

\section{Values of $\mathbf{p H}$}

Table 3 presents the changes in $\mathrm{pH}$ values of processed cheese sauces with added preservatives when fresh and during storage at room temperature up to 3 months. Fresh samples when compared expressed $\mathrm{pH}$ values 5.84, 5.83, 5.85 and 5.85 for processed cheese sauces with added preservatives nisin, nisin + natamycin, nisin + potassium sorbate and nisin + natamycin + potassium sorbate respectively. On the other hand the control cheese sauce with no added preservatives expressed $\mathrm{pH}$ value 5.82. The results indicated that all treatments with added preservative systems had $\mathrm{pH}$ values in a narrow range and were slightly higher than the control. Preservatives had no effect on the $\mathrm{pH}$ value and these could be related to the ingredients added when formulating the blends especially Ras cheese being in higher amount in the control treatment [12].

The $\mathrm{pH}$ values of different processed cheese sauces with added preservatives during storage up to 3 months at room temperature are also presented in Table $3 . \mathrm{pH}$ values changed to decrease gradually in all samples till the end of storage period. The decrease was more pronounced in the control treatment with no added preservatives. This could be related to the activity of the microorganisms present and propagated during storage [12]. Reduction in the $\mathrm{pH}$ also could be due to the enzymatic activity of the resistant enzymes present in sauces and hydrolysis of lactose and polymerized phosphate present in the emulsifying salts and their interaction with proteins.

\section{Soluble nitrogen content}

Changes in Soluble nitrogen content for processed cheese sauces using different preservatives systems when fresh and during storage up to 3 months are shown in Table 4 . Resultant processed cheese sauces with preservatives exhibited soluble nitrogen values of $0.779,0.766$, $0.777,0.765$ and 0.756 for control processed cheese sauce and processed cheese sauces with added nisin, nisin + natamycin, nisin + potassium sorbate and nisin + natamycin + potassium sorbate respectively. It is clear that differences in soluble nitrogen content among all treatments were slightly and non significant. These could be due to the differences in raw materials weight used to formulate the blend especially Ras cheese base.

Soluble nitrogen content increased in all treatments by extending the storage period. The increase were more obvious in control processed cheese sauce with added no preservatives especially at the end of storage period. Control processed cheese sauce had the highest content and that with added nisin + natamycin + potassium sorbate had the lowest comparing with the other treatments. These could be as a result of the increase in microbial count caused more solubilization in proteins [13]. Furthermore, changes during storage could be also due to the enzymatic activity of heat resistant proteinases present in the cheese sauces.

Table 4. Total volatile fatty acids $\left(\mathrm{TVFA}^{* *}\right)$ values of processed cheese sauces with different preservatives systems when fresh and during storage at $\left(25^{\circ} \mathrm{C}\right)$

\begin{tabular}{|c|c|c|c|c|}
\hline \multirow{2}{*}{ Treatments* $^{*}$} & \multirow{2}{*}{ Fresh } & \multicolumn{3}{|c|}{ Storage period/month } \\
\cline { 3 - 5 } & & $\mathbf{1}$ & $\mathbf{2}$ & $\mathbf{3}$ \\
\hline $\mathbf{C}$ & $11.58^{\mathrm{Ad}}$ & $13.75^{\mathrm{Ac}}$ & $18.70^{\mathrm{Ab}}$ & $21.26^{\mathrm{Aa}}$ \\
\hline $\mathbf{T}_{\mathbf{1}}$ & $11.08^{\mathrm{Ac}}$ & $11.49^{\mathrm{Bc}}$ & $14.06^{\mathrm{Bb}}$ & $18.97^{\mathrm{Ba}}$ \\
\hline $\mathbf{T}_{\mathbf{2}}$ & $11.39^{\mathrm{Ab}}$ & $12.19^{\mathrm{ABb}}$ & $13.08^{\mathrm{Bb}}$ & $17.81^{\mathrm{CBa}}$ \\
\hline $\mathbf{T}_{3}$ & $10.89^{\mathrm{Ac}}$ & $11.34^{\mathrm{Bc}}$ & $14.08^{\mathrm{Bb}}$ & $17.22^{\mathrm{CBa}}$ \\
\hline $\mathbf{T}_{\mathbf{4}}$ & $10.47^{\mathrm{Ac}}$ & $12.81^{\mathrm{ABb}}$ & $13.53^{\mathrm{Bb}}$ & $16.78^{\mathrm{Ca}}$ \\
\hline
\end{tabular}

*see Table (1)

$* * \mathrm{ml} \mathrm{NaOH} 0.1 \mathrm{~N} / 100 \mathrm{~g}$ cheese

A, B, C: Means with the same letter among treatments in the same storage period are not significantly different.

a, b, c: Means with the same letter in the treatment during storage periods are not significantly different. 


\section{Total volatile fatty acids (TVFA)}

Total volatile fatty acids values expressed as $\mathrm{ml} \mathrm{NaOH} 0.1 \mathrm{~N} / 100 \mathrm{~g}$ cheese sauce for processed cheese sauces with different preservatives when fresh and during storage are stated in Table 5. Fresh samples of processed cheese sauces with preservatives exhibited total volatile fatty acids values of $11.08,11.39,10.89$ and 10.47 for processed cheese sauces with nisin, nisin + natamycin, nisin + potassium sorbate and nisin + natamycin + potassium sorbate respectively. Control processed cheese sauce exhibited value of 11.58 for total volatile fatty acids. Cheese sauces when compared it can be seen that, control processed cheese sauce with no added preservatives had the highest total volatile fatty acids value and processed cheese sauce manufactured using nisin + natamycin + potassium sorbate had the lowest. These changes could be related to the differences in weight of added ingredients especially Ras cheese base or butter fat used for preparing the blends.

An increase in total volatile fatty acids of control sauce and sauces with different preservative systems were monthly observed up to 3 months of storage. This observed increase were directed as values being the highest in control processed cheese sauce and being the lowest in processed cheese sauce with added nisin + natamycin + potassium sorbate. These could be due to the differences in microbial activity during storage or due to the residual of heat resistant lipase activity in the base blends.

\section{Oil separation index}

Oil separation index (OSI) values of processed cheese sauces using different preservatives are presented in Table 6. Control processed cheese sauce with no preservatives possessed oil separation index value 20.12, while, sauces of nisin, nisin + natamycin, nisin + potassium sorbate and nisin + natamycin + potassium sorbate possessed 19.51, $19.40,19.58$ and 18.92. It is clear that the control processed cheese sauce had the highest value of oil separation index and processed cheese sauce with added nisin + natamycin + potassium sorbate had the lowest. Differences among treatments in oil separation index could

Table 5. Oil separation index of processed cheese sauces with different preservatives systems when fresh and during storage at $\left(25^{\circ} \mathrm{C}\right)$.

\begin{tabular}{|c|c|c|c|c|}
\hline \multirow{2}{*}{ Treatments* $^{*}$} & \multirow{2}{*}{ Fresh } & \multicolumn{3}{|c|}{ Storage period/month } \\
\cline { 3 - 5 } & & $\mathbf{1}$ & $\mathbf{2}$ & $\mathbf{3}$ \\
\hline $\mathbf{C}$ & $20.12^{\mathrm{Aa}}$ & $18.60^{\mathrm{Aa}}$ & $15.04^{\mathrm{Ab}}$ & $12.60^{\mathrm{Ac}}$ \\
\hline $\mathbf{T}_{\mathbf{1}}$ & $19.51^{\mathrm{Aa}}$ & $15.57^{\mathrm{Bb}}$ & $12.11^{\mathrm{Bc}}$ & $10.24^{\mathrm{Bc}}$ \\
\hline $\mathbf{T}_{\mathbf{2}}$ & $19.40^{\mathrm{Aa}}$ & $16.21^{\mathrm{Bb}}$ & $13.27^{\mathrm{ABc}}$ & $9.93^{\mathrm{Bd}}$ \\
\hline $\mathbf{T}_{\mathbf{3}}$ & $19.58^{\mathrm{Aa}}$ & $16.50^{\mathrm{Bb}}$ & $12.01^{\mathrm{Bc}}$ & $10.20^{\mathrm{Bc}}$ \\
\hline $\mathbf{T}_{\mathbf{4}}$ & $18.92^{\mathrm{Aa}}$ & $15.41^{\mathrm{Bb}}$ & $11.61^{\mathrm{Bc}}$ & $9.65^{\mathrm{Bd}}$ \\
\hline
\end{tabular}

*see Table (1)

A, B, C: Means with the same letter among treatments in the same storage period are not significantly different.

$\mathrm{a}, \mathrm{b}, \mathrm{c}$ : Means with the same letter in the treatment during storage periods are not significantly different.

Table 6. Viable total bacterial count $(\log \mathrm{cfu} / \mathrm{ml})$ of processed cheese sauces with different preservatives systems when fresh and during storage at $\left(25^{\circ} \mathrm{C}\right)$.

\begin{tabular}{|c|c|c|c|c|}
\hline \multirow{2}{*}{ Treatments* } & \multirow{2}{*}{ Fresh } & \multicolumn{3}{|c|}{ Storage period/month } \\
\cline { 3 - 5 } & & $\mathbf{1}$ & $\mathbf{2}$ & $\mathbf{3}$ \\
\hline $\mathbf{C}$ & 2.47 & 2.90 & 4.00 & 4.21 \\
\hline $\mathbf{T}_{\mathbf{1}}$ & 2.40 & 2.69 & 3.20 & 3.67 \\
\hline $\mathbf{T}_{\mathbf{2}}$ & 2.30 & 2.47 & 2.80 & 3.20 \\
\hline $\mathbf{T}_{\mathbf{3}}$ & 2.30 & 2.47 & 2.80 & 3.20 \\
\hline $\mathbf{T}_{\mathbf{4}}$ & 2.20 & 2.40 & 2.60 & 2.90 \\
\hline
\end{tabular}

*see Table (1) be due to the differences of F/DM content of processed cheese sauces. It also could be due to the strength of the protein matrix or protein, fat, thickening agents interaction and also fat rejection in resultant sauces [14].

When the samples of processed cheese sauces stored for 3 months a gradual decrease in oil separation index values were observed monthly in all treatments even the control. At the end of storage period control processed cheese sauce with no added preservatives had the highest value while processed cheese sauce with added nisin + natamycin + potassium sorbate had the lowest comparing with the other treatments. This decrease in all treatments during storage could be due to the increase in the fat rejection by the added thickening agents which alter the fat separation of the treatments [15]. Higher value in control treatment could be due to the hydrolysis in protein matrix as a result of microbial activity.

\section{Viscosity}

Viscosity values of processed cheese sauces manufactured with different preservatives are illustrated in Figure 1. Fresh samples of processed cheese sauces showed a decrease in viscosity values when the shear rate values increased. This behaviour indicate that the processed cheese sauce behave as pseudoplastic material which is expected with a material like cheese. Viscosity values of processed cheese sauces samples when compared showed that, control cheese sauce with no added preservatives had higher viscosity values than other treatments. It exhibited 5200, 4400, 3700, 3280, 2920 and 2420 at shear rates s${ }^{-1}$ $12.411,24.822,37.233,49.644,62.056$ and 74.467 . In spite of, processed cheese sauce with added nisin exhibited the lowest viscosity values and exhibited 4400, 2800, 2267, 2000, 1800 and 1667 at the same shear rate $\mathrm{s}^{-1}$ values in the same order. Differences in viscosity values among all treatments could be due to the effect of processing factors directed to effect on the protein - protein interaction, emulsifying salts and/or thickening agents.

After 3 months of storage at room temperature viscosity values were decreased in different rates in all stored processed cheese sauces. The decrease was so clear and obvious in control processed cheese sauce with no added preservatives. This could be due to the high number of detected microorganisms which may be affected the hydrolysis of protein and protein - protein interactions. Other factors such as changes in $\mathrm{pH}$ values, $\mathrm{SN}$ content, action of emulsifying salt, state of the protein and thickening agent in the emulsion could also affected the viscosity of stored sauces.

\section{Viable total bacterial count (VTBC)}

The viable total bacterial count (VTBC) of processed cheese sauces manufactured with added preservative systems when fresh and during storage for 3 months at room temperature are shown in Table 7. Detected viable total bacterial count as $\log \mathrm{cfu} / \mathrm{ml}$ in fresh samples were $2.47,2.40,2.30,2.30,2.20$ for control processed cheese sauce with no added preservatives and processed cheese sauces with added nisin, nisin + natamycin, nisin + potassium sorbate and nisin + natamycin + potassium sorbate respectively. The obtained data indicated that the control processed cheese sauce with no added preservatives had the highest total bacterial count compared to that with added preservatives. Among treatments with added preservatives, it is clear that processed cheese sauce with added nisin had higher viable total bacterial count than that with added mixtures of preservatives meanwhile, processed cheese sauce with added nisin + natamycin, nisin + potassium sorbate had the lowest. These means that the addition of preservatives in 
Table 7. Aerobic spore forming bacteria $(\log \mathrm{cfu} / \mathrm{ml})$ of processed cheese sauces with different preservatives when fresh and during storage at $\left(25^{\circ} \mathrm{C}\right)$.

\begin{tabular}{|c|c|c|c|c|}
\hline \multirow{2}{*}{ Treatments* } & \multirow{2}{*}{ Fresh } & \multicolumn{3}{|c|}{ Storage period/month } \\
\cline { 3 - 5 } & & $\mathbf{1}$ & $\mathbf{2}$ & $\mathbf{3}$ \\
\hline $\mathbf{C}$ & 2.00 & 1.84 & 1.69 & 1.47 \\
\hline $\mathbf{T}_{\mathbf{1}}$ & 2.00 & 1.84 & 1.74 & 1.30 \\
\hline $\mathbf{T}_{\mathbf{2}}$ & 2.00 & 1.69 & 1.60 & 1.00 \\
\hline $\mathbf{T}_{\mathbf{3}}$ & 1.95 & 1.66 & 1.47 & 1.00 \\
\hline $\mathbf{T}_{\mathbf{4}}$ & 1.80 & 1.47 & 1.30 & 0.75 \\
\hline
\end{tabular}

*see Table (1)

Table 8. Anaerobic spore forming bacteria $(\log \mathrm{cfu} / \mathrm{ml})$ of processed cheese sauces with different preservatives when fresh and during storage at $\left(25^{\circ} \mathrm{C}\right)$.

\begin{tabular}{|c|c|c|c|c|}
\hline \multirow{2}{*}{ Treatments* } & \multirow{2}{*}{ Fresh } & \multicolumn{3}{|c|}{ Storage period/month } \\
\cline { 3 - 5 } & & $\mathbf{1}$ & $\mathbf{2}$ & $\mathbf{3}$ \\
\hline $\mathbf{C}$ & ND & 0.70 & 1.00 & 1.30 \\
\hline $\mathbf{T}_{1}$ & ND & ND & 0.77 & 1.00 \\
\hline $\mathbf{T}_{2}$ & ND & ND & 0.60 & 0.75 \\
\hline $\mathbf{T}_{3}$ & ND & ND & 0.47 & 0.61 \\
\hline $\mathbf{T}_{4}$ & ND & ND & 0.30 & 0.42 \\
\hline
\end{tabular}

*see Table (1)

mixtures decreased the viable total bacterial count in the resultant processed cheese sauces. This could be due to the synergistic effect of the different preservatives when added in mixtures on the viable microorganisms present in the sauces that is higher than the effect of nisin when added individually. Gouda et al. [12] mentioned that the use of preservatives in mixtures has more effect on the inhibition of the bacterial growth.

By extending the storage period at the room temperature a gradual increase in total bacterial count were detected along the storage period. Control processed cheese sauce with no added preservatives had the highest detected number especially at the end of the storage period comparing with the other treatments. The lowest number were detected in processed cheese sauce with added mixture of nisin + natamycin and mixture of nisin + potassium sorbate. These could be due to the synergistic effect of the preservative system on decreasing the growth of the microorganisms along the storage period. Plockova et al. [16] mentioned that addition of nisin decreased total bacterial count in processed cheese during storage for 3 months and Wirjantoro et al. [17] mentioned that nisin was found to inhibit microbial growth for high moisture dairy products stored without refrigeration during storage for 150 days.

\section{Aerobic spore forming bacterial count}

The aerobic spore forming bacterial count in processed cheese sauces with added preservatives when fresh and during storage up to 3 months at room temperature are shown in Table 8. In fresh samples the detected aerobic spore forming bacteria as $\log \mathrm{cfu} / \mathrm{ml}$ were $2.00,2.00$, $2.00,1.95,1.80$ for control processed cheese sauce and processed cheese sauces with added nisin, nisin + natamycin, nisin + potassium sorbate and nisin + natamycin + potassium sorbate consecutively. The results revealed that the control processed cheese sauce, processed cheese sauce with added nisin and that with added nisin + natamycin had the same and higher spore forming bacterial count nevertheless, processed cheese sauce with added nisin + potassium sorbate and that with added nisin + natamycin + potassium sorbate had lower count than the other treatments. It is clear that the addition of preservatives in combinations had an effect on the spore formers counts.
During storage it observed that, in spite of the control treatment had the highest count up to the end of the storage period, aerobic spore forming bacterial count decreased gradually in all treatments including the control. Processed cheese sauces with added mixtures of nisin + potassium sorbate and nisin + natamycin + potassium sorbate as preservatives had lower count than that with added nisin. These could be due to the effect of added preservatives directed to a decrease in the spores viability during storage. Glass et al. [18] mentioned that spores are much more resistant to bacteriocins than vegetative cells and nisin has also been reported to inhibit spore germination at the pre-emergent swelling stage and to sensitize spores to heat treatment.

\section{Anaerobic spore forming bacterial count}

Table 9 presents the count of anaerobic spore forming bacteria in processed cheese sauces with added preservatives when fresh and during storage up to 3 months at room temperature. The obtained data indicated that there were no detected anaerobic spore forming bacteria in fresh samples of processed cheese sauces with added preservatives including the control.

During storage the count of anaerobic spore forming bacteria slightly increased in all treatments especially at the end of the storage period. Control processed cheese sauce had the highest detected number meanwhile; processed cheese sauce with added nisin + natamycin + potassium sorbate had the lowest. It is clear that the use of nisin, natamycin and potassium sorbate as a mixture were more effective in decreasing the propagation rate of anaerobic spore forming bacteria in the resultant processed cheese sauces. Plockova et al. [16] mentioned that addition of nisin inhibited the anaerobic spore counts in processed cheese during storage for 3 months and Moreno et al. [19] mentioned that addition of nisin has an effect on spore forming bacteria and inhibited Clostridium spp. \& Bacillus spp. in hard, semi hard and processed cheeses.

\section{Yeast and mould counts}

All fresh processed cheese sauces manufactured with added Table 9. Sensory evaluation of processed cheese sauces with different preservatives systems when fresh and during storage at $\left(25^{\circ} \mathrm{C}\right)$.

\begin{tabular}{|c|c|c|c|c|c|c|}
\hline \multirow{2}{*}{$\begin{array}{l}\text { Storage } \\
\text { period }\end{array}$} & \multirow{2}{*}{$\begin{array}{l}\text { Character } \\
\text { assessed }\end{array}$} & \multicolumn{5}{|c|}{ Treatments* } \\
\hline & & $\mathrm{C}$ & $T_{1}$ & $T_{2}$ & $T_{3}$ & $\mathbf{T}_{4}$ \\
\hline \multirow{4}{*}{ Fresh } & O. A. (20) & $18^{\mathrm{Aa}}$ & $18^{\mathrm{Aa}}$ & $18^{\mathrm{Aa}}$ & $18^{\mathrm{Aa}}$ & $18^{\mathrm{Aa}}$ \\
\hline & B\&T (40) & $38^{\mathrm{Aa}}$ & $38^{\mathrm{Aa}}$ & $38^{\mathrm{Aa}}$ & $38^{\mathrm{Aa}}$ & $38^{\mathrm{Aa}}$ \\
\hline & $A \& F(40)$ & $38.5^{\mathrm{ABa}}$ & $39^{\mathrm{Aa}}$ & $36^{\mathrm{Ca}}$ & $39^{\mathrm{Aa}}$ & $37^{\mathrm{BCa}}$ \\
\hline & $T(100)$ & $94.5^{\mathrm{Aa}}$ & $95^{\mathrm{Aa}}$ & $92^{\mathrm{Aa}}$ & $95^{\mathrm{Aa}}$ & $93^{\mathrm{Aa}}$ \\
\hline \multirow{4}{*}{1 Month } & O. A. (20) & $16.5^{\mathrm{Aab}}$ & $17.5^{\mathrm{Aab}}$ & $17^{\text {Aab }}$ & $17.5^{\mathrm{Aa}}$ & $17^{\text {Aab }}$ \\
\hline & B\&T (40) & $37^{\mathrm{Aa}}$ & $37^{\text {Aab }}$ & $37^{\mathrm{Aa}}$ & $37.5^{\mathrm{Aa}}$ & $37^{\text {Aab }}$ \\
\hline & A\&F (40) & $37.5^{\mathrm{ABa}}$ & $38^{\text {Aab }}$ & $35^{\mathrm{Cab}}$ & $38^{\text {Aab }}$ & $36^{\mathrm{BCa}}$ \\
\hline & $T(100)$ & $91^{\text {Aab }}$ & $92.5^{\text {Aab }}$ & $89^{\mathrm{Aa}}$ & $\mathbf{9 3}^{\mathrm{Aa}}$ & $90^{\text {Aab }}$ \\
\hline \multirow{4}{*}{2 Months } & O. A. (20) & $15^{\mathrm{Ab}}$ & $16^{\mathrm{Abc}}$ & $16^{\mathrm{Abc}}$ & $16.5^{\text {Aab }}$ & $16^{\mathrm{Abc}}$ \\
\hline & B\&T (40) & $34^{\mathrm{Bb}}$ & $36^{\mathrm{Abc}}$ & $36.5^{\text {Aab }}$ & $36.5^{\mathrm{Aab}}$ & $36.5^{\mathrm{Aab}}$ \\
\hline & A\&F (40) & $37^{\mathrm{Aa}}$ & $37^{\mathrm{Abc}}$ & $34^{\mathrm{Bb}}$ & $37^{\mathrm{Abc}}$ & $34^{\mathrm{Bb}}$ \\
\hline & T (100) & $86^{\mathrm{Ab}}$ & $89^{\mathrm{Abc}}$ & $86.5^{\text {Aab }}$ & $90^{\text {Aab }}$ & $86.5^{\mathrm{Abc}}$ \\
\hline \multirow{4}{*}{3 Months } & O. A. (20) & $14^{\mathrm{Bc}}$ & $15^{\mathrm{Ac}}$ & $15^{\mathrm{Ac}}$ & $15.5^{\mathrm{Ab}}$ & $15^{\mathrm{Ac}}$ \\
\hline & B\&T (40) & $33^{\mathrm{Bb}}$ & $34.5^{\mathrm{ABc}}$ & $35^{\mathrm{Ab}}$ & $35.5^{\mathrm{Ab}}$ & $35.5^{\mathrm{Ab}}$ \\
\hline & $A \& F(40)$ & $34^{\mathrm{BCb}}$ & $35.5^{\mathrm{ABc}}$ & $32^{\mathrm{Dc}}$ & $36^{\mathrm{Ac}}$ & $33^{\mathrm{CDb}}$ \\
\hline & $T(100)$ & $81^{\mathrm{Bc}}$ & $85^{\mathrm{ABc}}$ & $82^{\mathrm{ABb}}$ & $87^{\mathrm{Ab}}$ & $83.5^{\mathrm{ABC}}$ \\
\hline
\end{tabular}

O. A.: Outer appearance B\&T: Body\& texture A\&F: Aroma \& flavour T: Total score *see Table (1)

A, B, C: Means with the same letter among treatments in the same storage period are not significantly different.

$a, b$, c: Means with the same letter in the treatment during storage periods are not significantly different. 
preservatives and the control with no added preservatives were free from yeast and mould. Furthermore, yeast and mould could not be detected in all treatments along the storage up to the end of the storage period at room temperature, these results agree with Gouda et al. [12]. This could be due to the efficient heat treatment during processing and sanitization condition during manufacture and storage. Suleiman et al. [20] mentioned that the microbiological examination of processed cheese revealed in good hygienic condition might be due to the heat treatment.

\section{Sensory evaluation}

Sensory evaluation of processed cheese sauces manufactured by using different preservatives are shown in Table 10. The data revealed that, fresh samples of all processed cheese sauces including the control scored the same points and had the same properties for the outer appearance and inner appearance "body \& texture". All samples had creamy \& shiny outer appearance and smooth flow ability inner appearance. This resembles that, among all treatments for these properties were due to the use of the same ingredients to formulate the base blends before cooking. All formulated blends were contained the same raw materials except the added preservatives. It is clear that addition of preservatives in different ratios caused a slight variation among resultant sauces for aroma \& flavour properties. Consequently, aroma \& flavour of processed cheese sauces samples scored 38.5, 39.0, 36.0, 39.0 and 37.0 points for control processed cheese sauce and processed cheese sauces with nisin, nisin + natamycin, nisin + potassium sorbate, nisin + natamycin + potassium sorbate respectively. It is clear that, the processed cheese sauces with added nisin or nisin + potassium sorbate were more favourable than that with added natamycin. Lueck [21] mentioned that sorbate can be added directly into the product, this means that the use of nisin and/or potassium sorbate as preservatives had no effects on aroma \& flavour properties while, the use of natamycin in the formula caused slight bitterness and affected the aroma \& flavour properties of the resultant sauces.

When the storage period prolonged to 3 months it can be seen that, sensory properties of all sauces were influenced in different degrees. Processed cheese sauce with added nisin + potassium sorbate still the best and the more favourable sauce that when compared with the other sauces containing natamycin. Gouda et al. [12] mentioned that sodium sorbate had no effect on processed cheese aroma \& flavour till the end of the storage period even when used in combination with other preservatives. On the other hand, processed cheese sauce with no added preservatives had the lowest score points for all sensory properties. It is clear that the deterioration were more higher in control cheese sauce as a result of the increase in bacterial count directed to the activity of the bacterial enzymes and affected the sensory properties.

\section{Conclusion}

From the obtained data of this study it could be concluded that, addition of the preservatives in cheese sauce formula has a significant effect on the keeping properties. The use of preservative materials in combination form, i.e., in mixtures exhibited a high preservation effect and the using nisin + natamycin + potassium sorbate mixture was the most effective one for the product shelf life. From the view point of the sensory properties the results revealed that including natamycin in the preservatives mixtures has a slight negative effect on the organoleptic properties, meanwhile nisin + potassium sorbate mixture has no undesirable effect on the chemical, physical and sensory properties even after 3 months of storage so, it could be used as a preservative system in cheese sauce products.

\section{References}

1. Suhila A Saad (2002) The use of nontraditional additives in processed cheese manufacture and their effects on the resultant quality. M.Sc. Thesis, Food Sci. Department, Faculty of Agriculutre, Ain Shams Univ.

2. Awad RA (1996) Studies on emulsifying salt mixture for processed cheese. Ph. D Thesis, Food Sci. Department, Faculty of Agriculutre, Ain Shams Univ.

3. AOAC (2005) Official Methods of Analysis. 18th ed., Association of Official Analytical Chemists, Inc. Arlington. Virginia USA.

4. Ling ER (1963) Text Book of Dairy Chemistry. Vol. 2. Practical, 3 rd ed. Chapman and Hall Ltd. London.

5. Koiskowski F (1982) Cheese and Fermented Milk Foods. 2nd ed. F.V. Kosikowski and Associates, Brooktonale, New York.

6. Thomas MA (1973) The use of hard milk fat fraction in process cheese. Aust J Dairy Tech 49: 77-80.

7. Viturawong YP, Achayuthakan, Suphantharika M (2008) Gelatinization and rheological properties of rice starch/xanthan mixtures: Effect of molecular weight of xanthan and different salts. Food Chemistry 111: 106-114.

8. Oxoid (1990) The oxoid manual of culture media and other laboratory services. 6th Edition compiled by E. Y. Bridson, published by oxoid limited, Wad Rood, Basingstoke RG24 OPN, England.

9. Oxoid (2006) The oxoid manual of culture media and other laboratory services. 9th Edition compiled by E. Y. Bridson, published by oxoid limited, Wad Rood, Basingstoke Hampshire RG24 8 PW, England.

10. Meyer A (1973) Processed Cheese Manufacture. 1st ed. Food Trade Press. Ltd., London, UK.

11. SAS institute (2006) SAS User?s Guide/ STAT, Ninth edition. SAS Inst. Inc., Cary, $\mathrm{NC}$.

12. Gouda A, AI EL-Zayat (1988) Effect of some preservatives on the quality of processed cheese spreads. Egyptian J Food Science 16: 135-142.

13. Aly ME, Abdel-Baky AA, Farahat SM, Hana UUB (1995) Quality of processed cheese spread made using ultrafilterated retentates treated with some ripening agents. Int Dairy J 5: 191-208.

14. Garti N, Reichman D (1993) Hydrocolloids as food emulsifiers and stabilizers. Food structure 12: 411- 426

15. Hayashi M, Seguchi M (2004) Oil binding of heat treated waxy wheat starch granules and starch granule ghosts produced with concentrated KI and KI2. American Association of Cereal Chemists 81: 621-625.

16. Plockova M, Stepanek M, Demnerova K, Curda L, Svirakova E (1996) Effect of nisin for improvement in shelf - life and quality of processed cheese. Advances in Food Sciences 18: 78-83.

17. Wirjantoro TI, Lewis MJ, Grandison AS, Williams GC, Delves-Broughton J (2001) The effect of nisin on the keeping quality of reduced heat-treated milks. J Food Prot 64: 213-219. [Crossref]

18. Glass K, Doyle ME (2005) Safety of processed cheese. A review of the Scientific Literature. Food Research Institute. University of Wisconsin - Madison.

19. Moreno I, Vialta A, Lerayer ALS, Leitao MFF (1999) Control of spore- former bacteria in dairy products by nisin. Boletim da Sociedade - Brasileira de Ciencia e Tecnologia de Alimentos 33: 215-228.

20. Suleiman TAE, Abdalla MOM, EL-Haj NHM, Elsiddig HMO (2011) Chemical and microbiological evaluation of processed cheese available in Khartoum market, Sudan. American J Food Sci and Nutrition 1: 28-33.

21. Lück E (1990) Food applications of sorbic acid and its salts. Food Addit Contam 7 711-715. [Crossref].

Copyright: (C2015 Saad SA. This is an open-access article distributed under the terms of the Creative Commons Attribution License, which permits unrestricted use, distribution, and reproduction in any medium, provided the original author and source are credited. 